\title{
Bacterial and fungal diseases of potatoes in Finland
}

\author{
ESKO SEPPÄNEN \\ Department of Plant Pathology, Agricultural Research Centre, \\ SF-31600 Jokioinen, Finland
}

\begin{abstract}
Six bacterial and 18 fungal diseases are reviewed. Six and 28, respectively, of their causal organisms are presented. The occurrence and economic effects of these diseases are estimated.
\end{abstract}

Index words: potato, bacterial diseases, fungal diseases

\section{Introduction}

Potato is cultivated in Finland in a climatically extreme area where yield variation is high. Potatoes are usually grown in sandy soils thus often exposed to drought. The growing period is hardly 100 days (from May to September), while in Lapland it is far shorter often being limited by night frosts. The brief harvesting period lasting from two to three weeks is frequently quite cold with average temperatures of not more than $10^{\circ} \mathrm{C}$. The basic problem confronting modern, highly mechanized production is the harvesting of unripened tubers in extremely cold weather, when many tubers are scuffed and wounded. The storage period is long, even ten to eleven months.

Disease control has been mostly based on varietal resistance, and the knowledge required often obtained by variety trials. Chem- ical control was not common prior to the 1970 s, when greater specialization in potato production by farmers took place.

\section{Bacterial diseases}

B l a c k l e g and $\mathrm{s}$ of t $\mathrm{r}$ o t (Erwinia carotovora subsp. atroseptica and E. carotovora subsp. carotovora). The extent of $E$. carotovora contamination in 71 commercial seed potato stocks was investigated in 19811983. E. carotovora was detected in $82 \%$ of the stocks, and the average levels of contamination in the three years were 73,28 , and $10 \%$, respectively (HARJU 1985). Recontamination by $E$. carotovora was found after the second year of yield cultivation when pathogenfree seed potato stocks were investigated during four years' multiplication. E. caroto- 
vora subsp. atroseptica was the predominant soft rot organism isolated from tubers, and it was always associated with blackleg stems. Serotyping of Eca isolates indicated that in addition to serogroup I, three other serogroups exist (Harju and KanKILA 1987).

B a c t e r i a 1 ring rot (Corynebacterium sepedonicum) was first found at the end of the 1960s. Seppänen and Heinämies (1972) identified the pathogen and mapped the incidence of disease based on 542 tuber samples, 321 tubers on average, from seed stocks collected from different parts of the country. The disease occurred quite commonly in Oestrobothnia but only sporadically in other parts of the country. The degree of infection was low, on average one to two per cent. In subsequent official inspections the situation has not improved with regard to the exportation of potatoes (RAUTAPÄÃ and VIRTANEN 1985).

$\mathrm{P}$ i n k e y e (Pseudomonas fluorescens) occurs in abundance on tubers grown in light soils in wet conditions. External symptoms may be confused with those of tuber blight (SEPPÃnen $1981 \mathrm{a}, 1982 \mathrm{~d}$ ).

C o m m o n s c a b (Streptomyces scabies) and $\mathrm{r}$ u s s e t s c a b (Streptomyces sp.) also occur to a certain extent every year, the latter mainly affects Bintje. Their occurrence is the consequence of warm and dry weather during the first half of July, and yearly variation is wide. The use of varietal resistance to common scab has been the only means of controlling it, and results of screenings have been reported by RoIVAINEN (1938), YLIMÄKI (1951 b, 1960 a), JAMALAINEN and Seppänen (1965), VARIS (1965, 1970, 1975), JoY (1980), HÄKKINEN (1981), and Mustonen (1985). Attention has been paid to scab resistance in potato breeding, which has resulted in the fairly resistant cultivar Pito and Hankkijan Tuomas. Trials to control common scab with PCNB-preparate were carried out by YLIMÄKı and HÄNNINEN (1957), YLIMÄKı (1958), but the treatment was too expensive for general use. HeINÄMIES and SEPPÄNEN (1971) attempted to study the morphological, physiological, and pathogenic properties of the potato scab organism.

\section{Fungal diseases during the season}

L a t e bligh t and $\mathrm{t} \mathrm{uber} \mathrm{blight}$ (Phytophthora infestans). Late blight was the most important fungal disease of potato until the 1970s. Its great annual fluctuation was ascertained long ago (Grotenfelt 1910), and the question of the efficacy of chemical control as a complement to varietal resistance is still a problem.

RAINIO (1937) attempted to estimate the occurrence and economic impact of these diseases by employing information collected from different parts of the country over a number of years. His results confirmed that in some years the diseases are quite common causing great losses, while in other years there is hardly any blight in the whole country. Corresponding results have been reported by $\mathrm{SI}_{\mathrm{I}}$ MOJOKı (1963), YLlö (1963), and SEPPÄNEN (1971) based on blight observations in variety trials carried out over many years. SEPPÄNEN (1971) analyzed material based on observations made from variety trials over more than 30 years in different parts of the country. He concluded that in southern Finland leaf blight occurred nearly every year, in four years out of five on average, but the incidence of a severe blight epidemic was only one year out of three and less northwards. The lowering of tuber yield due to premature defoliation was estimated to be less than $10 \%$ on average, even in southern Finland, and that of tuber blight lesser still. The only study dealing with the fungus itself has been conducted by MA. KELÃ (1966) on the overwintering of the fungus and other factors influencing the rise of epidemics. After the severe late blight epidemic in 1953, Pohjakallo (1954) compared the pathogenicity of some isolates from different parts of the country.

The control of late and tuber blights has mainly been based on varietal resistance, which has been considered a fairly important property for the use of a cultivar (KOSKINEN 
1932, Sauli et al. 1935, Meurman 1936, ValLE et al. 1938, Roivainen 1939, Huttunen et al. 1946, Brummer 1950, Linja-Aho 1955, VARIS 1960, 1965, 1970, 1975, Ylló 1963, SEPPÄNEN 1967, 1971, JoY 1980, HÄKKINEN 1981, Mustonen 1985). Seppänen (1967, 1971 ) introduced the term 'relative resistance to late blight', i.e. the resistance of a given cultivar to late blight compared with its earliness. In Finnish potato breeding consideration has also been given to resistance to late blight, and such cultivars as Jaakko, Veto, and Hankkijan Tuomas, are notably resistant in relation to their earliness. Interest in chemical control had been slight though the results of screenings using different preparates were promising (Jamalainen 1933, Ylimä́o 1951, $1953,1954,1956,1960,1961)$. The use of chemical control to complement varietal resistance was not common until the 1970s, when the mean area under potato cultivation of a single farm increased (SEPPÄNEN 1977). Nowadays chemical control ranging from one to three treatments is a common procedure most often employing the systemic metalaxyl + mancozeb preparate, usually complemented with mangan preparates (SEPPÄNEN 1987). Vine killing is often used to control the tuber blight.

$\mathrm{P}$ o t a $\mathrm{t}$ o w a $\mathrm{r} \mathrm{t}$ (Synchytrium endobioticum). Potato wart was first found in 1924 , probably as a result of the importation of potatoes in 1921-1924 (LIRO 1927, RAINIO 1928). Since then, it has been encountered in numerous localities mainly in southern Finland. In field plots there has hardly been a single finding, but the disease has been found in home gardens (HiLli 1932, Lehtola 1944, Ollila 1949, YlimäKı 1950, 1955, Aura 1962, 1971). Hilli (1932) conducted a larger study on the distribution of the disease in Finland and abroad.

In potato breeding wart resistance is required of all new cultivars, therefore resistant cultivars are generally recommended to growers.

This disease was widely known prior to this first finding. Trials to obtain good, wart- resistant cultivars were started and resistant cultivars were strongly recommended to growers. As early as 1925 , a law was enacted prohibiting the growing of susceptible cultivars in localities where potato wart had been identified.

Together all the above precautions have been effective in the prevention of this disease.

$\mathrm{S} t \mathrm{e} \mathrm{m}$ c a $\mathrm{n} \mathrm{k}$ e $\mathrm{r}$ (Rhizoctonia solani) is quite common but seldom causes significant losses. Seppänen (1985) studied its incidence in five fields cultivated with potatoes as a monoculture for $15-25$ years. Seed tubers of three susceptible cultivars treated with thiabendazole (ULV) were planted as usual. Plant samples were collected about one month later and analyzed. As the presence of stem canker was either negligible or absent, it was concluded that monoculture is not associated with the disease.

Wh i t e c ollar caused by the same fungus is common but considered insignificant in the potato.

B l a c k s c u r f and R hizoct on i a $\mathrm{s} \mathrm{c}$ a b (Rhizoctonia solani) are rather common but seldom the cause of poor quality in table potatoes (SEPPÄNEN 1972). However, they may have a significant role as carriers of the fungus into the next season. According to tests screening fungicides for seed dressing, varying yield increases have been obtained, and the treatment is therefore recommended (Seppănen 1974, Pietilä 1987).

$\mathrm{P}$ o w d e r y s c a b (Spongospora subterranea) occurs nearly every year in slight amounts but is not significant (SEPPÃNEN 1972).

E a r l y b l i g t (Alternaria solani) is rather common in certain cultivars during warm seasons but without importance.

$\mathrm{V}$ e r t i c illi u m wilt (Verticillium albo-atrum) is rare and has been found only in a few farms in southern Finland (SEPPÄNEN 1983 e).

$\mathrm{S}$ t a $1 \mathrm{k}$ b r e a k (Sclerotinia sclerotiorum) is considered uncommon. However, in 1986 , as a consequence of a wet and cold late season, it occurred generally in some locali- 
ties, even causing economic losses (SEPPÄNEN 1986).

\section{Storage diseases}

D r y r o t s (Fusarium sp.) and G a n $\mathrm{g} r$ e $\mathrm{n}$ e (Phoma exigua var. exigua and $P$. $e$. var. foveata) are the most common storage diseases. JAmAlainen (1943 a, 1943 b, 1944) isolated eight Fusarium species from potato tubers, but at that time dry rots were insignificant compared with tuber blight (OLLILA 1947). As late as the beginning of 1970s, SEPPÄNEN (1972) determined tuber blight to be the most common cause of decay in tubers in packaged table potatoes. In some samples of Bintje grown from stocks originating from recently imported seed stocks, the causal agents of gangrene were isolated and identified. In 1975 , about nine thousand tons of seed potatoes were imported, and at the same time storage diseases, dry rots and gangrene, also appeared. This created considerable problems under Finnish growing conditions, where the scuffing and wounding of tubers had been until then the main problems. The causal organisms were later isolated and identified (14 Fusarium and 2 Phoma species), some characteristics of the fungi were clarified and the importance of the diseases as well as the resistance of our cultivars to them were estimated (SEPPÄNEN $1980 \mathrm{a}, 1980 \mathrm{~b}, 1981 \mathrm{~b}$, 1981 c, 1981 d, 1982 a, 1982 b, 1982 c, 1983 a, $1983 \mathrm{~b}, 1983 \mathrm{c}, 1983 \mathrm{~d})$. In the 1980 s there were fewer problems due to dry rots and gangrene. One reason for this is the activities of the Seed Potato Center founded in 1976 (PIETARINEN and SEPPĀNEN 1981).

$\mathrm{S}$ i l v e r s c u $\mathrm{r}$ (Helminthosporium solani) and $\mathrm{s} \mathrm{k} \mathrm{i} \mathrm{n} \mathrm{s} \mathrm{p} \mathrm{ot} \mathrm{(Polyscutalum}$ pustulans) are quite common storage diseases (SEPPÄNEn 1972), especially after wet late seasons and harvesting conditions, but hardly ever cause significant economic losses. The only method of control recommended is that of drying the tubers as soon as possible after harvest.

$\mathrm{P}$ i n k r o t (Phytophthora erythroseptica) is rare, the first findings were made by SEPPÃNEn (1971). There have been numerous findings from all over the country since then, but only a couple are of importance.

$\mathrm{L}$ e a $\mathrm{k}$ or wat e ry wound rot (Pythium ultimum) occurs sporadically and may be harmful in some table potato stocks wounded at harvest.

$\mathrm{B} \mathrm{l} \mathrm{a} \mathrm{c} \mathrm{k} \mathrm{d} \mathrm{o} \mathrm{t} \mathrm{(Colletotrichum} \mathrm{atramen-}$ tarium) is insignificant (SEPPÄNEN 1972).

\section{Summary}

Six bacterial and 18 fungal diseases and their causal organisms 6 and 29, respectively, were presented. Their occurrence and economic importance were roughly estimated.

Potato late blight and tuber blight were the diseases of greatest importance and most difficult to control until the 1970s. Nowadays most farmers use chemical control to assure the quantity and quality of the yield. Since the mid-1970s, Fusarium dry rots and gangrene have become the most serious problem. With the aid of developments in seed potato production, and due to the increased knowledge and skill of growers the situation is under control. The bacterial diseases presented here occur every year but seldom cause great crop losses. Black leg and soft rot, as well as common scab must be coped with because the possibilities to control them are limited. The eradication of ring rot appears to be slow and laborious. As to other diseases, more attention ought to be paid to stem canker and black scurf as well as to skin spot. Other diseases are only sporadically harmful. 


\section{References}

AurA, K. 1962. Perunasyöpä. Koetoim. ja Kảyt. 19: 6-7.

- 1971. Perunasyöpă. Koetoim. ja Kăyt. 28: 29, 32.

Brummer, V. 1950. Peruna. Summary: Potatoes. Siemenjulkaisu 1950: 58-70.

Grotenfelt, G. 1910. Perunarutto ja sen esiintyminen Suomessa. Maahenki II: 484-492.

HARJu, P. 1985. Siemenperunan tyvi- ja märkämătătartunta. Koetoim. ja Käyt. 42: 26.

- \& Kankila, J. 1987. Contamination of seed potato stocks by Erwinia carotovora in Finland. Abstr. of Conf. Papers and Posters of the 10th Trienn. Conf. of the EAPR.: 430.

Heinàmies, H. \& Seppänen, E. 1971. Morphological, physiological and pathogenic properties of potato scab organism in Finland. Ann. Agric. Fenn. 10: 174-180.

Hııı, A. 1932. Perunasyövăn (Synchytrium endobioticum [Schilb.] Perc.) leviämisen syistă Suomessa ja ulkomailla. Abstract: The reasons of the spread of potato wart (Synchytrium endobioticum [Schilb.] Perc.) in Finland and abroad. Valt. Maatal. koetoim. Julk. 46: 1-249.

Huttunen, E., Brummer, V., Heikinheimo, A. \& Pohjan. HEıмо, O. 1946. Tuloksia vertailevista lajikekokeista Tammistossa 1938-45. Summary: Results of comparative variety trials at Tammisto $1938-45$. Siemenjulkaisu 1946: 21-108.

Hăkinen, S. 1981. Perunan lajikekokeet Etelä-Savon koeasemalla v. 1975-1980. Etelä-Savon koeaseman tiedote 3: $1-26$.

Jamalainen, E. A. 1933. Perunaruton esiintymisestä ja torjuntatoimenpiteistä. Suomen Kasvinsuojeluseuran Julk. 2: 6-10.

- 1943 a. Über die Fusarien Finnlands I. Staatl. Landw, Versuchstăt. Veröff. 122: 1-26.

- 1943 b. Über die Fusarien Finnlands. II. Staatl. Landw. Versuchstät. Veröff. 123: 1-24.

- 1944. Über die Fusarien Finnlands. III. Staatl. Landw. Versuchstăt. Veröff. 124: 1-23.

— \& Seppànen, 1965. Perunalajikkeiden ruvenkestävyys. Summary: Trials on resistance of potato varieties to scab. Maatal. ja Koetoim. 19: 165-171.

Joy, P. 1980. Peruna. Summary: Potatoes. Siemenjulkaisu 1980: 101-110.

Koskinen, Y. K. 1932. Perunan laatukokeiden tuloksia vuosilta 1920-1930. Valt. Maatal. koetoim. Julk. 44: $1-121$.

Lehtola, V. B. 1944. Perunasyövästă ja sen torjunnasta Suomessa. Maatalous 9: 168-172.

Linja-Aно, M. 1955. Peruna. Summary: Potatoes. Siemenjulkaisu 1955: 52-68.

Lıro, J. 1927. Perunasyöpä. Valt. Maatal.koetoim. Tied.ant. 6: 1-4.

Meurman, O. 1936. Perunan laatukokeiden tuloksia Maatalouskoelaitoksen puutarhaosastolla vuosina 1928
-1935. Valt. Maatal.koetoim. Tied.ant. 111: 1-18.

Mustonen, L. 1985. Perunalajikkeet eri kăyttötarkoituksiin. Koetoim. ja Käyt. 42: 10.

MÄKELÄ, K. 1966. Factors influencing the epidemics of Phytophthora infestans (Mont.) de Bary in Finland. Acta Agr. Fenn. 104, 2: 1-100.

Ollil.A, L. 1947. Tuhosienien merkityksestä perunavarastojen turmelijoina Suomessa. Summary: On the significance of fungous diseases in stored potatoes in Finland. Maatal.tiet. Aikak. 19: 89-98.

- 1949. Perunasyöpä. Valt. Maatal.koetoim. Tied.ant. 218: $1-8$.

Pietarinen, E. \& Seppänen, E. 1981. Start of seed potato production in Finland. A review. Ann. Agric. Fenn. 20: $184-187$.

Pı́tıLĀ, L. 1987. Seitti perunan vaivana. Kăytănnőn Maamies 36, 4: 87 .

Raınıo, A. J. 1928. Perunasyöpä tehdasalueilla Suomessa. Suomen Sahanomistajain Maanviljelysyhdistyksen Vuosikertomus: $1-8$.

- 1937. Perunaruton aiheuttamat tuhot Suomessa ja sen esiintymiseen vaikuttavista tekijöistä. Referat: Die durch den Kartoffelschimmel verursachten Schäden in Finnland und über die auf sein Auftreten einwirkender Faktoren. Staatl. Landwirtschaftl. Ver.tăt. Veröff. 95: $1-47$.

RAutAPĀĀ, J. \& Virtanen, R. 1985. Perunan rengasmätä levinnyt uhkaavasti. Maatal.hall. Aikak. 15, 2: 21-25.

Roivainen, H. 1938. Perunarupi ja sen torjuminen. Valt. Maatal.koetoim. Tied.ant. 142: 1-7.

- 1939. Perunarutto ja sen torjuminen. Valt. Maatal.koetoim. Tied.ant. 155: 1-9.

Sauli, J. O., Valle, O., Huttunen, E. \& Rancken, G. 1935. Tuloksia vertailevista laatukokeista Tammistossa 1930-34. Referat: Ergebnisse vergleichender Sortenversuche auf Tammisto 1930-34. Siemenjulkaisu 1935: $20-92$.

Seppannen, E. 1967. Perunalajikkeidemme rutonkestävyys. Summary: Resistance of potato varieties to late blight. Maatal. ja Koetoim. 21: 116-120.

- 1971. Influence of weather conditions and late blight on the yields of potatoes in Finland, 1931-62. Ann. Agric. Fenn. 10: 65-109.

- 1972. On the external quality of table potatoes in Finland and factors influencing it. Acta Agric. Fenn. 11: 119-134.

- 1974. Siemenperunan peittaus. Kăytănnön Maamies 23, 4: 13-14.

- 1977. Kehittyvă perunanviljelymme. Käytännön Maamies 26, 2: 43-44.

- 1980 a. Studies on potato gangrene in Finland. Acta Agric. Fenn. 19: 173-179.

- 1980 b. On the growth of some Fusarium ssp. in cv. 
Bintje under different environmental conditions. Potato Res. 23: 478.

- 1981 a. Peruna tukehtui mărkyyteen. Koetoim. ja Käyt. 38: 44.

- 1981 b. Fusariums of the potato in Finland I. On the Fusarium species causing dry rot in potatoes. Ann. Agric. Fenn. 20: 156-160.

- 1981 c. Fusariums of the potato in Finland II. On the growth optima of Fusarium species in tubers of cv. Bintje. Ann. Agric. Fenn. 20: 161-176.

- 1981 d. Fusariums of the potato in Finland III. Varietal resistance of potato tubers to some Fusarium species. Ann. Agric. Fenn. 20: 177-183.

- 1982 a. Fusariums of the potato in Finland IV. Variation of tuber resistance to storage diseases before and after harvesting. Ann. Agric. Fenn. 21: 123-130.

- 1982 b. Fusariums of the potato in Finland V. Further investigations on the growth optima of Fusarium species in potato tubers. Ann. Agric. Fenn. 21: 162 -168 .

- 1982 c. Further studies on varietal differences in resistance to potato gangrene. Ann. Agric. Fenn. 21: $155-161$.

- 1982 d. Erfarenheter av bladmögelsommaren in Finland. Växtskyddsrapporter. Jordbruk 20: 57-59.

- 1983 a. Fusariums of the potato in Finland VI. Varietal tuber resistance to Fusarium species. Ann. Agric. Fenn. 22: 8-17.

- 1983 b. Fusariums on the potato in Finland VII. Yield decrease caused by pathogens of dry rots and gangrene. Ann. Agric. Fenn. 22: 110-114.

- 1983 c. Fusariums of the potato in Finland VIII. Occurrence of the pathogens causing potato dry rot and gangrene. Ann. Agric. Fenn. 22: 115-119.

- 1983 d. Different tolerances of 14 Fusarium spp. to thiophanatemethyl. Res. note. Ann. Agric. Fenn. 22: $120-121$.

- 1983 e. Perunarupi vuoden 1982 vitsaus. Koetoim. ja Kåyt. 40, 1: 4.

- 1985. Maalevintäiset taudit yksipuolisessa perunanviljelyssă. Käytănnön Maamies 34: 20.

- 1986. Peruna kasvukautena 1986 - Varsikuolio vioitti kasvustoja. Koetoim. ja Käyt. 43: 49.

- 1987. Tarkennusta rutontorjuntaan. Käytännön Maamies 36, 6: 32-33.

- \& HeInÃmies, H. 1972. Occurrence of potato ring rot caused by Corynebacterium sepedonicum (Speck. \& Kotth.) in Finland. Ann. Agric. Fenn. 11: 315-319.
Sıмолокı, P. 1963. Kasvitaudeista Pohjois-Pohjanmaalla. Summary: On plant diseases in North Ostrobothnia: Maatal. ja Koetoim. 17: 218-222.

Valle, O., Huttunen, E. \& Rancken, G. 1938. Tuloksia vertailevista laatukokeista Tammistossa 1935-37. Referat: Ergebnisse vergleichender Sortenversuche auf Tammisto 1935-37. Siemenjulkaisu 1938: 53-106.

VARIS, E. 1960. Peruna. Summary: Potatoes. Siemenjulkaisu 1960: 67-85.

- 1965. Peruna. Summary: Potatoes. Siemenjulkaisu 1965: 58-71.

- 1970. Peruna. Summary: Potatoes. Siemenjulkaisu 1970: 66-77.

- 1975. Peruna. Summary: Potatoes. Siemenjulkaisu 1975: 73-78.

- 1975. Hankkijan Tuomas. (Engl. sum.) Siemenjulkaisu 1975: 166-169.

YııмĀKı, A. 1950. Perunasyövăn levinneisyydestă ja torjuntamahdollisuuksista maassamme. Koetoim. ja Kảyt. 7, 4: 3 .

- 1951 a. Perunaruttoa torjumaan. Maamies 36: 279.

- 1951 b. Miksi perunat ovat rupisia. Maamies 36: 312, 318.

- 1953. Perunaruttoruiskutus kannattaa meillăkin. Koetoim. ja Käyt. 10, 6: 3-4.

- 1954. Perunarutto - pitkä kanto perunaviljelyssämme. Maatalous 47: 251-254.

- 1955. Perunasyövän levinneisyys ja torjunta Suomessa. Zusammenf: Verbreitung und Bekămpfung von Kartoffelkrebs in Finnland. J. Sci. Agric. Soc. Finl. 27: 199-220.

- 1956. Uusia kokemuksia perunaruton torjunnasta. Koetoim. ja Käyt. 13, 6: 22.

- 1958. The control of potato scab with PCNB preparations. J. Sci. Agric. Soc. Finl. 30: 210.

- 1960 a. Perunarupi. Käytännön Maamies 1960 (4): 170.

- 1960 b. Perunaruton kemiallinen torjunta. Maatal. ja Koetoim. 14: 234-242.

- 1961. Perunarutto ja sen torjuminen. Koetoim. ja Kăyt. 18: 1, 4, 8.

— \& Hãnninen, P. 1957. Perunarupeakin voidaan torjua. Koetoim. ja Käyt. 14, 5: 19.

YLLO, L. 1963. Perunan lajikekokeiden tuloksia Kasvinviljelylaitoksella Tikkurilassa v. 1931-48. Summary: Results of variety trials on potato at the Department of Plant Husbandry in Tikkurila, 1931-58. Acta Agric. Fenn. 2: 109-133. 


\section{SELOSTUS}

\section{Perunan bakteeri- ja sienitaudit Suomessa}

\section{Esko Seppänen}

Kasvitautiosasto, Maatalouden tutkimuskeskus, 31600 Jokioinen

Katsauksessa on esitetty Suomessa todetut 6 bakteerija 18 perunan sienitautia sekä niiden aiheuttajat ( 6 bakteeria ja 28 sienilajia). Tautien esiintymisrunsaus ja taloudellinen merkitys on arvioitu. Perunan lehtirutto ja mukularutto (aiheuttaja Phytophthora infestans) ovat olleet merkitykseltaaăn suurimmat aina 1970-luvulle asti. Tuolloin ruton kemiallinen torjunta yleistyi ammattiviljelijöiden keskuudessa ja nykyisin rutto ei ole aiheuttanut torjuntavaikeuksia.

1970-luvun puolivälissă tuotiin maahamme noin 9000 tonnia siemenperunaa, jonka mukana seurasi runsaasti kuivamădăn ja Phomamădăn aiheuttajia. Nämă meillă aikaisemmin vain niukasti esiintyneet taudit ovat siitä lăhtien olleet taloudellisesti merkittăvimmät. Niiden aiheuttajat 14 Fusarium-lajia, joista $F$. solani var. coeruleum ja $F$. avenaceum ovat yleisimmăt, sekả 2 Phoma-lajia, on kartoitettu ja niiden tărkeimmăt ominaisuudet selvitetty. Siementuotannon kehittämisen ja viljelijäin tiedon ja taidon parantamisen avulla on nämäkin taudit saatu hallintaan.
Bakteeritaudit ovat jokavuotisena kiusana, joskin ne harvoin aiheuttavat suuria menetyksiä. Tyvimädän ja märkämädän (Erwinia carotovora) samoin kuin tavallisen perunaruvenkin (Streptomyces scabies) kanssa on tultava toimeen, sillä keinot niiden torjumiseksi ovat rajalliset. Rengasmädän (Corynebacterium sepedonicum) hăvittäminen nảyttảả kestävän odotettua kauemmin. Muista taudeista versolaikku ja seittirupi (Rhizoctonia solani) sekä kănsärupi (Polyscutalum pustulans) vaativat nykyistä enemmăn huomiota. Bakteeritaudit punasilmă (Pseudomonas fluorescens) ja verkkorupi (Streptomyces sp.) sekă sienitaudit perunasyöpă (Synchytrium endobioticum), perunaseitti ja kuoriroso (Rhizoctonia solani), kuorirokko (Spongospora subterranea), perunapolte (Alternaria solani), näivetystauti (Verticillium albo-atrum), varsikuolio (Sclerotinia sclerotiorum), harmaa hilse (Helminthosporium solani), punamătă (Phytophthora erythroseptica) ja sydänmätä (Pythium ultimum) ovat vain harvoin taloudellisesti merkittäviä. 